\title{
A Quantas Andam os Honorários Médicos?
}

De nosso conhecimento jamais vivenciamos parelha situação: honorários médicos congelados há mais de seis anos e enervante indiferença governamental.

Constitucionalmente não são os governos os nossos prepostos para garantirem assistência médica para todos? Não são pagos os tributos (aliás sempre crescentes) para tal? Porventura verificamos globalmente assistência médica prestada pelo governo mais universal e gabaritada? Infelizmente temos que admitir que não.

Nesse cenário surgiram os seguros-saúde verdadeiros intermediários entre os pacientes e os médicos. Qual, infelizmente, e na grande maioria o escopo destas empresas? O lucro, o maior possivel.

O médico, ator principal (logicamente após o paciente), tornou-se operário das empresas de capital. E os governos, o que fizeram? Omitiram-se. Omitem-se.

Em face dos honorários médicos congelados há muito o que diz a Agência Nacional de Saúde Suplementar? Nada. Omite-se uma vez mais e diz não ter qualquer ingerência na relação desigual entre médicos e operadoras de saúde.

A quem recorrer?

A Central de Convênios Médicos e o Conselho Regional de Medicina do Rio de Janeiro acordaram Assembléia Geral a ser realizada brevemente. Tentar-se-á reverter a vergonhosa situação. Será tarefa fácil? Não acreditamos. É dificil lutar contra o poder econômico.

E o Poder Público? Não deveria o Governo ser o primeiro interessado em estabelecer diálogo efetivo e conciliatório quando a resultante é o bem estar da população? Não caberia ao Governo a responsabilidade única de prestar assistência médica de qualidade aos cidadãos? Não foi o Governo eleito para defender os reais interesses de toda a população?

Vemos, infelizmente, estar longínqua a reversão do atual quadro de assistência médica no país.

A Diretoria 